\title{
Wpływ wybranych czynników na wybór kierunku studiów i plany zawodowe studentów ratownictwa medycznego
}

\author{
Ewa Smoleń', Elżbieta Cipora' \\ ${ }^{1}$ Państwowa Wyżzza Szkoła Zawodowa im. J. Grodka w Sanoku \\ Smoleń E, Cipora E. Wpływ wybranych czynników na wybór kierunku studiów i plany zawodowe studentów ratownictwa medycznego. Med \\ Og Nauk Zdr. 2015; 21(1): 33-38. doi: 10.5604/20834543.1142356
}

\begin{abstract}
I Streszczenie
Wstęp. Do czynników decydujących o wyborze kierunku studiów przez młodych ludzi zalicza się: zainteresowania, osobiste predyspozycje i możliwości. Istotne znaczenie ma również wpływ najbliższych, massmediów oraz perspektywa znalezienia zatrudnienia i rozwoju zawodowego.

Cel pracy. Określenie determinantów korelujących z wyborem kierunku studiów oraz poznanie planów zawodowych studentów ratownictwa medycznego.

Materiał i metody. Badania przeprowadzono w 2013 roku metodą sondażu diagnostycznego. W celu zebrania materiału empirycznego zastosowano autorski kwestionariusz ankiety. Grupę badaną stanowiło 133 studentów kierunku ratownictwo medyczne Państwowej Wyższej Szkoły Zawodowej (PWSZ) im. J. Grodka w Sanoku.

Wyniki. Przekonanie przez inne osoby to dla większości badanych, głównie studentów niestacjonarnych, motyw decydujący o wyborze ratownictwa medycznego jako zawodu. W przypadku mieszkańców miast oraz studentek najczęściej o wyborze studiów na kierunku ratownictwo medyczne decydował przypadek. Kobiety mniej optymistycznie niż mężczyźni oceniły możliwość zatrudnienia w zawodzie. Mężczyźni i osoby w przedziale wiekowym 31-35 lat oraz mieszkańcy miast planowali podjąć pracę po studiach w pogotowiu ratunkowym, natomiast kobiety i studenci studiów niestacjonarnych w szpitalnym oddziale ratunkowym. Pracę w Państwowej Straży Pożarnej zamierzali podjąć studenci studiów stacjonarnych oraz mieszkańcy wsi. Ponad połowa badanych wysoko oceniła swoje szanse na zatrudnienie zgodnie z wyuczonym zawodem. W opinii respondentów studia, w tym nauczanie praktyczne i teoretyczne, przygotowują absolwentów do pracy zawodowej. Studenci wskazali na istotne znaczenie powołania w zawodzie ratownika medycznego.

Wnioski. W badanej grupie zmiennymi korelującymi z wyborem kierunku studiów były: płeć, miejsce zamieszkania, wiek studentów oraz tryb studiowania.
\end{abstract}

\section{- Słowa kluczowe}

studenci, zawód, ratownictwo medyczne

\section{WSTĘP}

Ratownik medyczny to młody zawód, który w Polsce powstał w latach dziewięćdziesiątych XX wieku. Obecnie podejmowane działania w zakresie kształcenia, badań naukowych, podstaw prawnych, założeń teoretycznych i etycznych zmierzają do profesjonalizacji zawodu [1]. Wzrastające oczekiwania wobec zawodu wynikające z potrzeby dostosowywania do obowiązujących standardów postępowania w służbach ratowniczych oraz zmieniające się zapotrzebowanie na wysoką jakość usług, wymagają odpowiedniego przygotowania kadry medycznej do pracy w systemie ratownictwa [2]. Wysoki poziom wykształcenia powinien pozwolić ratownikowi medycznemu na działanie w stanach bezpośredniego zagrożenia życia oraz szeroki zakres samodzielności zawodowej [3]. Według Kodeksu etyki zawodowej ratownika medycznego ratownik medyczny podejmuje działania w zgodzie z najnowszą wiedzą naukową oraz z najwyższą starannością. Zgodnie z ustawą o Państwowym Ratownictwie Medycznym i Kodeksem etyki zawodowej, od ratownika medycznego wymaga się stałego i systematycznego uzupełniania i doskonalenia wiedzy oraz umiejętności zawodowych [4]. W Polsce pierwsi

Adres do korespondencji: Ewa Smoleń, Państwowa Wyższa Szkoła Zawodowa im. J. Grodka w Sanoku, ul. Mickiewicza 21, 38-500 Sanok

E-mail: ewasmolen@op.pl

Nadesłano: 24 maja 2014 roku; Zaakceptowano: 15 września 2014 roku absolwenci medycznych szkół zawodowych (policealnych) uzyskali tytuł ratownika medycznego w 1994 roku, w Poznaniu. Od roku akademickiego 2000/2001 kształcenie ratowników medycznych rozpoczęto na poziomie wyższym, tj. na studiach pierwszego stopnia - licencjackich [2]. W Sanoku pierwszy nabór do szkoły policealnej miał miejsce w 1999 roku, a w roku akademickim 2010/2011 w Państwowej Wyższej Szkole Zawodowej im. Jana Grodka w Sanoku pierwsza grupa studentów rozpoczęła naukę na kierunku ratownictwo medyczne. W 2013 roku 27 studentów studiujących w trybie stacjonarnym oraz $36 \mathrm{w}$ niestacjonarnym ukończyło studia licencjackie na kierunku ratownictwo medyczne [5]. Ratownik medyczny to zawód z grupy medycznych, który cechuje wysoki poziom zaangażowania i podejmowanie wyzwań, konieczność silnej motywacji wewnętrznej i samokontroli oraz duża odporność na stres, co związane jest z podejmowaniem ryzyka i szybkich decyzji $[1,2]$. Zawód ratownika medycznego w Polsce cieszy się szacunkiem i zaufaniem społecznym, pomimo że jest młodą profesją. Wysoki prestiż zawodu wynika z odpowiedzialności, poświęcenia oraz profesjonalizacji ratowników medycznych. Ratowanie ludzkiego życia wymaga podejmowania działań wynikających z najnowszej wiedzy teoretycznej i praktycznej, co zobowiązuje ratowników medycznych potrzebę ciągłego kształcenia i podnoszenia kwalifikacji zawodowych. W specyfice pracy ratownika medycznego mieszczą się pewne 
zagrożenia i niebezpieczeństwa. Wskazali na nie w swoich badaniach Fedorczuk i wsp. analizując wyjazdy Pogotowia Ratunkowego we Wrocławiu [6].

Wybór zawodu to decyzja, która rzutuje na całe życie [7]. Przemyślane podjęcie studiów, zgodne z zainteresowaniami i predyspozycjami, zwiększa efektywność kształcenia, a w przyszłości ułatwia dostosowanie się do rynku pracy oraz planowanie rozwoju zawodowego [8]. Świadome przygotowanie do wykonywania zadań zawodowych zapewnia wysoką jakość usług i zwiększa bezpieczeństwo w realizacji zadań zawodowych [4].

Tematyka kształtowania motywacji pracowników jest zagadnieniem popularnym dla naukowców w zakresie zarządzania zasobami ludzkimi w organizacji [9]. W psychologii motywacja wewnętrzna określana jest jako wrodzona skłonność do szukania wyzwań, rozwijania i doskonalenia własnych zdolności, eksperymentowania i uczenia się [10]. Według Kozłowskiego motywacja wewnętrzna to „siła”, która skłania do osiągnięcia wartości „samych w sobie” oraz pobudza do działania „samego w sobie”. Przejawia się jako zainteresowanie lub zamiłowanie do czegoś [11]. Jak wynika z dotychczas prowadzonych badań i obserwacji, dla organizacji najcenniejszy jest pracownik z wewnętrzną motywacją i kreatywnością do działania [12]. Zasadne jest więc empiryczne poznanie czynników, jakie wpływają na wybór kierunku kształcenia, w analizowanym przypadku kierunku - ratownictwo medyczne.

Wśród czynników warunkujących wybór określonego kierunku studiów należy wymienić: zainteresowania, chęć zdobycia pracy, wyznawane wartości oraz sytuację rodzinną. W przypadku kierunków medycznych, głównym motywem podjęcia studiów bez względu na wiek są zainteresowania. W dalszej kolejności zwiększenie szans na dobrą pracę oraz wpływ rodziny i nauczycieli [13].

\section{CEL PRACY}

Określenie czynników korelujących z wyborem kierunku studiów oraz planów zawodowych studentów ratownictwa medycznego.

\section{MATERIAŁ I METODY}

Badania przeprowadzono w 2013 roku metodą sondażu diagnostycznego. Zastosowano autorski kwestionariusz ankiety. Grupę badaną stanowiło 133 studentów studiów stacjonarnych i niestacjonarnych kierunku ratownictwo medyczne PWSZ im. J. Grodka w Sanoku. Dane poddano analizie statystycznej z zastosowaniem testu Chi-kwadrat. W celu określenia korelacji między zmiennymi a motywami wyboru kierunku studiów i planami zawodowymi przyjęto poziom istotności $p<0,05$. W analizie statystycznej uwzględniono takie zmienne jak: wiek i płeć badanych, miejsce zamieszkania, wykształcenie oraz tryb studiów.

\section{WYNIKI}

Większość studentów stacjonarnych (75,0\%) stanowiły osoby niepracujące, w porównaniu do niestacjonarnych, gdzie niepracujący stanowli zaledwie 8,7\% - p<0,001. Najczęściej osobami niepracującymi byli studenci poniżej 25. roku życia $(66,3 \%)-p<0,001$. Wykazano słabą zależność między aktywnością zawodową a miejscem zamieszkania - studenci zamieszkujący wieś częściej byli osobami aktywnymi zawodowo $(\mathrm{p}=0,03)$. Występowała umiarkowana zależność, która wskazywała, że badane kobiety $(82,6 \%)$ zdecydowanie częściej niż mężczyźni $(31,8 \%)$ pozostawały bez pracy (p<0,001).

Motywami decydującymi o wyborze ratownictwa medycznego jako zawodu dla studentów stacjonarnych częściej były koszty kształcenia, a dla niestacjonarnych przekonanie do wyboru kierunku przez inne osoby oraz ciekawość. Bez względu na tryb studiów (stacjonarne/niestacjonarne) najczęściej wskazywaną odpowiedzią przez badanych była odległość uczelni od miejsca zamieszkania (tabela 1).

Tabela 1. Czynniki decydujące o wyborze studiów w sanockiej uczelni, z uwzględnieniem formy studiowania

\begin{tabular}{|c|c|c|c|}
\hline \multirow{2}{*}{ Wybór PWSZ w Sanoku } & & \multicolumn{2}{|c|}{ Forma studiów } \\
\hline & & Stacjonarne & Niestacjonarne \\
\hline \multirow{2}{*}{ Odległość } & $\mathrm{N}$ & 36 & 32 \\
\hline & $\%$ & $56,3 \%$ & $46,4 \%$ \\
\hline \multicolumn{4}{|c|}{$p=0,26$} \\
\hline \multirow{2}{*}{ Koszty } & $\mathrm{N}$ & 16 & 1 \\
\hline & $\%$ & $25,0 \%$ & $1,4 \%$ \\
\hline \multicolumn{4}{|c|}{$p<0,001$} \\
\hline \multirow{2}{*}{ Przypadek } & $\mathrm{N}$ & 7 & 11 \\
\hline & $\%$ & $10,9 \%$ & $15,9 \%$ \\
\hline \multicolumn{4}{|c|}{$\mathrm{p}=0,40$} \\
\hline \multirow{2}{*}{ Przekonanie przez inne osoby } & $\mathrm{N}$ & 4 & 18 \\
\hline & $\%$ & $6,3 \%$ & $26,1 \%$ \\
\hline \multicolumn{4}{|c|}{$\mathrm{p}<0,001$} \\
\hline \multirow{2}{*}{ Ciekawość } & $\mathrm{N}$ & 0 & 5 \\
\hline & $\%$ & $0,0 \%$ & $7,2 \%$ \\
\hline \multicolumn{4}{|c|}{$p=0,03$} \\
\hline \multirow{2}{*}{ Inne } & $\mathrm{N}$ & 2 & 1 \\
\hline & $\%$ & $3,1 \%$ & $1,4 \%$ \\
\hline \multicolumn{4}{|c|}{$\mathrm{p}=0,52$} \\
\hline
\end{tabular}

Studenci powyżej 41. roku życia częściej wskazywali, że o wyborze sanockiej uczelni decydowało przekonanie ich przez inne osoby $(\mathrm{p}=0,002)$ - tabela 2. Przypadek wpływał częściej na wybór kierunku studiów przez mieszkańców miast niż wsi $(\mathrm{p}=0,04)$. Pozostałe motywy wyboru PWSZ w Sanoku były zbliżone u studentów mieszkających na wsi i w miastach ( $>00,1)$. Niemal dwukrotnie więcej kobiet (21,7\%) niż mężczyzn (11,8\%) wybór PWSZ jako miejsca studiowania przypisało przypadkowi $(\mathrm{p}=0,21)$.

Większość studentów stacjonarnych $(81,3 \%)$ i niestacjonarnych $(78,3 \%)$ powtórnie rozpoczęłaby studia na kierunku ratownictwo medyczne. Nie zaobserwowano różnic w deklaracji o powtórnym podjęciu studiów na wybranym kierunku w poszczególnych przedziałach wiekowych $(\mathrm{p}=0,97)$. Zbliżony odsetek mieszkańców miast $(78,0 \%)$ oraz wsi $(81,1 \%)$ wyraził opinię, o powtórnym podjęciu nauki na kierunku ratownictwo medyczne. Co dziesiąty mieszkaniec wsi (10,8\%) oraz co dwudziesty miasta $(5,1 \%)$ nie podjąłby powtórnie nauki na tym kierunku. Dwukrotnie więcej studentów 
mieszkających w mieście $(16,9 \%)$ niż na wsi $(8,1 \%)$ nie wyraziło opinii na ten temat $-(\mathrm{p}=0,18)$. Nie wykazano różnic istotnych statystycznie w grupie kobiet i mężczyzn w zakresie powtórnego wyboru kierunku ratownictwo medyczne $(\mathrm{p}=0,20)$.

Niemal co czwarty student ratownictwa medycznego $(24,1 \%)$ nie zastanawiał się nad perspektywą zatrudnienia po studiach, a co piąty (19,5\%) uważał, że nie uzyska zatrudnienia w swoim zawodzie w Polsce. Nie wykazano zależności istotnej statystycznie $(\mathrm{p}=0,15)$ między trybem studiowania (stacjonarnym i niestacjonarnym) a opiniami studentów o możliwości zatrudnienia po ukończeniu studiów.

Tabela 2. Czynniki decydujące o wyborze studiów w PWSZ w Sanoku a wiek studentów

\begin{tabular}{|c|c|c|c|c|c|c|c|}
\hline \multirow{2}{*}{ Czynnik } & & & \multicolumn{5}{|c|}{ Wiek (w latach) } \\
\hline & & & Poniżej & $26-30$ & $31-35$ & $36-40$ & Powyżej \\
\hline \multirow{2}{*}{ Odległość } & \multirow{2}{*}{ Tak } & $\mathrm{N}$ & 43 & 12 & 8 & 4 & 1 \\
\hline & & $\%$ & $53,8 \%$ & $42,9 \%$ & $53,3 \%$ & $57,1 \%$ & $33,3 \%$ \\
\hline \multicolumn{8}{|c|}{$p=0,83$} \\
\hline \multirow{2}{*}{ Koszty } & \multirow{2}{*}{ Tak } & $\mathrm{N}$ & 14 & 0 & 3 & 0 & 0 \\
\hline & & $\%$ & $17,5 \%$ & $0,0 \%$ & $20,0 \%$ & $0,0 \%$ & $0,0 \%$ \\
\hline \multicolumn{8}{|c|}{$p=0,10$} \\
\hline \multirow{2}{*}{ Przypadek } & \multirow{2}{*}{ Tak } & $\mathrm{N}$ & 11 & 5 & 1 & 1 & 0 \\
\hline & & $\%$ & $13,8 \%$ & $17,9 \%$ & $6,7 \%$ & $14,3 \%$ & $0,0 \%$ \\
\hline \multicolumn{8}{|c|}{$p=0,82$} \\
\hline \multirow{2}{*}{$\begin{array}{l}\text { Przekonanie } \\
\text { przez innych }\end{array}$} & \multirow{2}{*}{ Tak } & $\mathrm{N}$ & 7 & 10 & 2 & 1 & 2 \\
\hline & & $\%$ & $8,8 \%$ & $35,7 \%$ & $13,3 \%$ & $14,3 \%$ & $66,7 \%$ \\
\hline \multicolumn{8}{|c|}{$p=0,002$} \\
\hline \multirow{2}{*}{ Ciekawość } & \multirow{2}{*}{ Tak } & $\mathrm{N}$ & 4 & 0 & 0 & 1 & 0 \\
\hline & & $\%$ & $5,0 \%$ & $0,0 \%$ & $0,0 \%$ & $14,3 \%$ & $0,0 \%$ \\
\hline \multicolumn{8}{|c|}{$p=0,37$} \\
\hline \multirow{2}{*}{ Inne } & \multirow{2}{*}{ Tak } & $\mathrm{N}$ & 1 & 1 & 1 & 0 & 0 \\
\hline & & $\%$ & $1,3 \%$ & $3,6 \%$ & $6,7 \%$ & $0,0 \%$ & $0,0 \%$ \\
\hline \multicolumn{8}{|c|}{$p=0,71$} \\
\hline
\end{tabular}

Źródło: opracowanie własne

Wiek badanych nie wpływał na ich opinię dotyczącą możliwości zatrudnienia po studiach $(\mathrm{p}=0,25)$. Różnic istotnych statystycznie nie wykazano również w zakresie opinii o możliwości zatrudnienia po studiach wśród mieszkańców miast i wsi $(p=0,13)$. Kobiety zdecydowanie mniej pozytywnie od mężczyzn oceniły swoje szanse na zatrudnienie w zawodzie $(\mathrm{p}=0,005)$ - tabela 3 .

Optymalnym miejscem pracy dla przyszłych absolwentów ratownictwa medycznego w PWSZ w Sanoku było pogotowie ratunkowe $(\mathrm{p}=0,003)$. Natomiast Państwową Straż Pożarną (PSP) jako miejsce pracy częściej wskazywali studenci kształcący się w trybie stacjonarnym $(\mathrm{p}=0,02)$ - tabela 4 .

W odniesieniu do pozostałych miejsc pracy deklarowanych przez badanych, tj. Szpitalnego Oddziału Ratunkowego (SOR), Wodnego Ochotniczego Pogotowia Ratunkowego (WOPR), Górskiego Ochotniczego Pogotowia Ratunkowego (GOPR), Centrum Powiadamiania Ratunkowego (CPR), służb wojskowych, uczelni - nie wykazano zależności istotnych statystycznie. Pogotowie ratunkowe najczęściej jako miejsce pracy wskazywali studenci będący w przedziale wiekowym 31-35 lat $(\mathrm{p}=0,01)$. W przypadku pozostałych
Tabela 3. Możliwość zatrudnienia po ukończeniu studiów a płeć badanych

\begin{tabular}{lccc}
\hline \multirow{2}{*}{ Możliwość zatrudnienia } & & \multicolumn{3}{c}{ Płeć } \\
\cline { 2 - 4 } Nie & & Kobieta & Mężczyzna \\
\hline \multirow{2}{*}{ Tak } & $\mathrm{N}$ & 10 & 16 \\
\cline { 2 - 4 } & $\%$ & $43,5 \%$ & $14,5 \%$ \\
\hline \multirow{2}{*}{ Nie zastanawiałam/em się } & $\mathrm{N}$ & 8 & 67 \\
\cline { 2 - 4 } & $\%$ & $34,8 \%$ & $60,9 \%$ \\
\hline \multirow{2}{*}{ Ogółem } & $\mathrm{N}$ & 5 & 27 \\
\hline & $\mathrm{N}$ & $21,7 \%$ & 110 \\
\cline { 2 - 4 } & $\%$ & $100,0 \%$ & $100,0 \%$ \\
\hline
\end{tabular}

Żródło: opracowanie własne

Tabela 4. Miejsce pracy po zakończeniu studiów a forma studiów

\begin{tabular}{lrcc}
\hline \multirow{2}{*}{ Miejsce pracy } & & \multicolumn{2}{c}{ Forma studiów } \\
\cline { 2 - 4 } Pogotowie ratunkowe & & Stacjonarne & Niestacjonarne \\
\hline & $\mathrm{N}$ & 28 & 48 \\
\hline \multirow{2}{*}{ Państwowa Straż Pożarna } & $\mathrm{p}=0,003$ & $43,8 \%$ & $69,6 \%$ \\
\hline & $\mathrm{N}$ & 13 & 4 \\
\hline & $\%$ & $20,3 \%$ & $5,8 \%$ \\
\hline
\end{tabular}

Żródło: opracowanie własne

miejsc pracy związki okazały się nieistotne statystycznie. Wystąpiła słaba zależność istotna statystycznie, między miejscem zamieszkania studentów a wyborem optymalnego miejsca pracy po zakończeniu studiów. Badani zamieszkujący miasta najczęściej chcieliby podjąć pracę w pogotowiu ratunkowym ( $\mathrm{p}=0,008)$, a zamieszkujący wieś w PSP $(0,004)$ - tabela 5. Pozostałe miejsca pracy w podobnym nasileniu były wykazywane przez zbliżone odsetki studentów mieszkających na wsi i w miastach $(\mathrm{p}>0,1)$.

Tabela 5. Potencjalne miejsce pracy studentów po ukończeniu studiów

\begin{tabular}{|c|c|c|c|}
\hline \multirow{2}{*}{ Miejsce pracy } & & \multicolumn{2}{|c|}{ Miejsce zamieszkania } \\
\hline & & Wieś & Miasto \\
\hline \multirow{2}{*}{ Pogotowie ratunkowe } & $\mathrm{N}$ & 35 & 41 \\
\hline & $\%$ & $47,3 \%$ & $69,5 \%$ \\
\hline \multicolumn{4}{|c|}{$p=0,008$} \\
\hline \multirow{2}{*}{ Państwowa Straż Pożarna } & $\mathrm{N}$ & 15 & 2 \\
\hline & $\%$ & $20,3 \%$ & $3,4 \%$ \\
\hline \multicolumn{4}{|c|}{$p=0,004$} \\
\hline
\end{tabular}

Źródło: opracowanie własne

Studentki częściej w porównaniu do studentów jako optymalne miejsce pracy deklarowały SOR $(\mathrm{p}=0,001)$, natomiast mężczyźni preferowali $(47,8 \%)$ podjęcie pracy w pogotowiu ratunkowym $(\mathrm{p}=0,32)$ - tabela 6. Mężczyźni częściej wskazywali na pracę w WOPR, PSP, służbie wojskowej oraz na uczelni, natomiast kobiety w GOPR i CPR. Nie były to jednak zależności istotne statystycznie. 
Tabela 6. Miejsce pracy po zakończeniu studiów w opinii badanych

\begin{tabular}{lrcc}
\hline \multirow{2}{*}{ Miejsce pracy } & & \multicolumn{2}{c}{ Płeć } \\
\cline { 2 - 4 } & & Kobieta & Mężczyzna \\
\hline \multirow{2}{*}{ Szpitalny Oddział Ratunkowy } & $\mathrm{N}$ & 8 & 7 \\
\hline & $\%$ & $34,8 \%$ & $6,4 \%$ \\
\hline \multirow{2}{*}{ Pogotowie ratunkowe } & $\mathrm{p}=0,001$ & & 65 \\
\hline & $\mathrm{N}$ & 11 & $59,1 \%$ \\
\hline & $\%$ & $47,8 \%$ & \\
\hline
\end{tabular}

Źródło: opracowanie własne

Studia pierwszego stopnia na kierunku ratownictwo medyczne zapewniają przygotowanie teoretyczne i praktyczne do samodzielnej pracy w systemie ratownictwa medycznego. Zapytano studentów kierunku ratownictwo medyczne PWSZ w Sanoku o samoocenę przygotowania w procesie nauczania do pracy w zawodzie ratownika medycznego. Oceny dokonywali w skali Likerta (tj. od 1 do 5). Przygotowanie do podjęcia pracy zawodowej po uzyskaniu tytułu licencjata studenci PWSZ w Sanoku ocenili na poziomie średnim (tabela 7).

Zawód ratownika medycznego związany jest realizacją zadań na rzecz zdrowia i życia osób. Praca z człowiekiem w sytuacji zagrożenia zdrowia i życia wymaga określonych sposobów postępowania ratowniczego wobec każdego, bez względu na wiek, płeć, rasę wyznanie, narodowość, poglądy. Zapytano studentów o znaczenie powołania i przygotowania do podjęcia pracy zawodowej po zakończeniu studiów. Wskaźnik zaufania pacjentów do ratownika medycznego podczas wykonywania zadań zawodowych w opinii badanych studentów był przeciętny. Studenci PWSZ, przyszli pracownicy systemu ratownictwa wskazali na wysokie znaczenie powołania w zawodzie ratownika medycznego (tabela 7).

W badaniu podjęto także próbę oceny wartości studentów, które są istotne w ich życiu. Były to: duma, prestiż, kontakty, kariera, poświęcenie, wygoda, pieniądze. Uznanie poszczególnych wartości za istotne przez osoby studiujące w trybie stacjonarnym i niestacjonarnym nie było zróżnicowane. Natomiast nieistotne statystycznie okazało się zróżnicowanie opinii badanych w różnym wieku na temat wartości ważnych w pracy ratownika medycznego.

Tabela 7. Rozkład odpowiedzi studentów na temat zaufania pacjentów do zawodu ratownika medycznego, znaczenia powołania i przygotowania do pracy

\begin{tabular}{lcccc}
\hline & \multicolumn{2}{c}{$\begin{array}{c}\text { Zaufanie pacjen- } \\
\text { tów do ratownika } \\
\text { medycznego }\end{array}$} & Powołanie & $\begin{array}{c}\text { Przygotowanie do } \\
\text { podjęcia pracy zawo- } \\
\text { dowej }\end{array}$ \\
\hline $\mathrm{N}$ & 133 & 133 & 133 \\
\cline { 2 - 5 } Ważne & Braki danych & 0 & 0 & 0 \\
\hline Średnia & 3,3910 & 3,8045 & 3,4962 \\
\hline Odchylenie standardowe & 1,03598 & 1,25806 & 1,13901 \\
\hline Minimum & 1,00 & 1,00 & 1,00 \\
\hline Maksimum & 5,00 & 5,00 & 5,00 \\
\hline
\end{tabular}

Źródło: opracowanie własne

Opinie studentów mieszkających na wsi i w mieście, dotyczące wartości uznanych za ważne w pracy ratownika medycznego, były porównywalne $(p>0,4)$. Jedynie prestiż jako wartość w pracy ratownika medycznego częściej wskazywany był przez studentów zamieszkujących miasto $(\mathrm{p}=0,05)$. Podobne opinie dotyczące wartości ważnych w pracy ratownika medycznego wyraziły kobiety oraz mężczyźni (p>0,1).

Dla ponad połowy studentów (60,9\%) zdrowie okazało się najważniejszą wartością w życiu, dającą szczęście. Nieznacznie mniejszy odsetek badanych $(59,4 \%)$ wskazał na udany związek małżeński. Natomiast nieco ponad jedna trzecia badanych $(34,6 \%)$ uznała dzieci za najważniejszą wartość w życiu. Zbliżony odsetek $(33,1 \%)$ wskazał na pracę zawodową, a jedna czwarta badanych $(24,8 \%)$ za źródło szczęścia uznała pieniądze. Dla $14,3 \%$ byli to przyjaciele, a dla $9,0 \%$ optymizm, życzliwość i szacunek otoczenia. W następnej kolejności studenci wymieniali: uczciwość $(8,3 \%)$, wiarę $(7,5 \%)$, silny charakter $(6,8 \%)$, wolność $(6,0 \%)$. Najmniejsze znaczenie przypisali wykształceniu (3,0\%). Nie wykazano zależności istotnych statystycznie między trybem studiowania (stacjonarny i niestacjonarny) a wyborami najważniejszych w życiu wartości. Jedynie nieznacznie częściej dla studentów stacjonarnych przyjaciele byli wyznacznikiem szczęścia, ale była to zależność słabo istotna statystycznie $(\mathrm{p}=0,02)$. Uzyskane wyniki wskazują, że bez względu na tryb studiów, szczęściem dla badanych w znacznym stopniu były: zdrowie i udane małżeństwo, a najrzadziej badani wskazywali na wykształcenie. Nie wykazano zależności między poziomem wykształcenia a wartościami uznanymi za ważne przez studentów w pracy ratownika medycznego $(p>0,5)$. Źródłem szczęścia dla studentów mieszkających na wsi i w mieście były zbliżone wartości ( $\mathrm{p}>0,1)$.

\section{DYSKUSJA}

Ratownik medyczny to młody zawód. Niewiele jest doniesień w piśmiennictwie dotyczących motywów podejmowania studiów na tym kierunku kształcenia oraz planów zawodowych absolwentów. Dotąd badania określające determinanty wyboru kierunku ratownictwo medyczne prowadziła Rębak, natomiast w aspekcie planów zawodowych Szczepańska $[15,16]$. Badania tego typu są bardziej popularne w zawodach pielęgniarki i lekarza $[17,18,19]$. W Polsce ratownik medyczny ma prawo i obowiązek doskonalenia zawodowego i ustawicznego kształcenia. Jedną z możliwości jest ukończenie studiów wyższych na kierunku ratownictwo medyczne [20].

Większość studentów zarówno na studiach stacjonarnych, jak i niestacjonarnych powtórnie podjęłaby naukę w Sanoku. Nie wykazano różnic w ponownym rozpoczęciu studiów w opinii badanych w poszczególnych grupach wiekowych, z uwzględnieniem ich miejsca zamieszkania oraz płci. Absolwenci kierunku ratownictwo medyczne na Uniwersytecie Medycznym (UM) w Lublinie wyrazili najwyższy stopień satysfakcji z wybranego kierunku studiów $(8,27)$ spośród studentów innych kierunków prowadzonych na uczelni (średnia 7,31) [14].

Niemal co dziesiąta osoba studiująca na kierunku ratownictwo medyczne w Sanoku na studiach stacjonarnych pracowała na stanowisku ratownika medycznego. Na studiach niestacjonarnych była to grupa $75,0 \%$. W Lublinie 10,0\% absolwentów przed zakończeniem studiów podjęło pracę w zawodzie [14].

Osoby studiujące w PWSZ jako główny motyw wyboru studiów na kierunku ratownictwo medyczne wskazały, bez względu na tryb studiów, odległość od miejsca zamieszkania. Studenci studiów niestacjonarnych oraz osoby powyżej 
41. roku życia jako główny powód podjęcia studiów podały przekonanie ich przez inne osoby, natomiast osoby będace na studiach stacjonarnych wskazały na niskie koszty studiowania. Przypadek decydował o podjęciu kształcenia w PWSZ w Sanoku, głównie w grupie mieszkańców miast oraz wśród kobiet. Autorzy raportu, dotyczącego opinii absolwentów Uniwersytetu Medycznego w Lublinie po roku akademickim 2012/2013, wskazali, że badani w głównej mierze kierowali się renomą uczelni (56,0\%), w drugiej kolejności dogodną lokalizacją szkoły wyższej (51,0\%). Na trzecim miejscu wymieniali wysoki poziom nauczania (47,0\%). W najmniejszym stopniu o wyborze uczelni decydowały niedostanie się na inny kierunek studiów (9,0\%) oraz perspektywa kariery zawodowej (7,0\%) [14].

Jedna czwarta studentów nie zastanawiała się nad podjęciem pracy po ukończeniu studiów na kierunku ratownictwo medyczne. Natomiast co piąty student deklarował pewność uzyskania zatrudnienia w zawodzie ratownika medycznego w Polsce. Wiek badanych, tryb studiowania, miejsce zamieszkania nie różnicowały opinii dotyczących możliwości uzyskania zatrudnienia w zawodzie. Jedynie płeć była determinantem różnicującym opinię na temat szans na pracę w zawodzie. Mężczyźni ocenili swoje szanse zdecydowanie lepiej niż kobiety. Studenci, którzy ukończyli UM w Lublinie w większości $(64,0 \%)$ planowali kontynuować kształcenie na studiach magisterskich. Szanse na znalezienie zatrudnienia w zawodzie ocenili bardzo nisko $(2,47)$, a nieco lepiej zatrudnienie poza zawodem [14].

Studenci PWSZ kształcący się na studiach stacjonarnych oraz mieszkańcy wsi jako optymalne miejsce swojej pracy wskazywali na PSP, a studenci niestacjonarni i mieszkańcy miasta deklarowali pogotowie ratunkowe. Kobiety studiujące ratownictwo medyczne częściej niż mężczyźni wskazywały na podjęcie pracy w szpitalnych oddziałach ratunkowych, mężczyźni natomiast $\mathrm{w}$ pogotowiu ratunkowym. W badaniach własnych wykazano, że przyszli ratownicy planowali podjać pracę przede wszystkim w Polsce. W badaniach Szczepańskiej i wsp. 44,6\% studentów ratownictwa medycznego zamierzała pozostać w Polsce [16]. Niemal wszyscy absolwenci kierunku ratownictwa medycznego w Lublinie (98,0\%) wyrazili gotowość zmiany miejsca zamieszkania bądź wyjazdu poza województwo celem znalezienia pracy (82,0\%). Grupa 76,0\% studentów lubelskich deklarowała nawet ewentualność migracji poza granice kraju w poszukiwaniu zatrudnienia [14].

Studia wyższe pierwszego stopnia na kierunku ratownictwo medyczne przygotowują do samodzielnego wykonywania medycznych czynności ratunkowych. Absolwent kierunku dysponuje wiedzą z zakresu nauk społecznych i specjalistycznych oraz umiejętnościami z zakresu nauk medycznych pozwalających na podejmowanie działań w stanach nagłych u dorosłych i dzieci $[15,21]$.

$\mathrm{W}$ badaniach własnych studenci wysoko ocenili przygotowanie do wykonywania zawodu. Ponad połowa studentów UM w Lublinie (67,0\%) wskazała na dobre przygotowanie do wykonywania zawodu, natomiast co piąty student (20,0\%) stwierdził, że jest w „pełni przygotowany” do pracy w zawodzie [14]. Ratownicy medyczni - absolwenci studiów licencjackich w badaniach Rębak i wsp. wyrazili opinię, że posiadają wysoki poziom wiedzy teoretycznej, natomiast absolwenci dwuletniej szkoły policealnej wskazali poziom zdecydowanie niższy. Najważniejszym przedmiotem w opinii badanych, na który przeznacza się zbyt małą ilość czasu, są medyczne czynności ratunkowe [21].
Zawód ratownika medycznego jest zawodem o wysokim poziomie zaufania społecznego. W badaniach własnych studenci deklarowali średni wskaźnik zaufania pacjentów do ratownika medycznego. Studenci PWSZ podkreślali istotne znaczenie powołania w zawodzie ratownika medycznego. Dla studentów uczelni lubelskiej $(43,5 \%)$ powołanie miało także ważne znaczenie w wykonywaniu zawodu oraz wyborze kierunku studiów [14].

Poznanie opinii ratowników dotyczących motywów wyboru kierunku studiów może stanowić podstawę do umocnienia pozytywnych elementów kształcenia oraz wprowadzania zmian w zakresie tych elementów, które mają niekorzystny wpływ na proces kształcenia.

\section{WNIOSKI}

$\mathrm{W}$ badanej grupie zmiennymi korelującymi z wyborem kierunku studiów były: płeć, miejsce zamieszkania, wiek studentów oraz tryb studiowania.

\section{PIŚMIENNICTWO}

1. Goniewicz M. Kształcenie ratowników medycznych w Polsce - przeszłość, teraźniejszość, przyszłość. W: Goniewicz M, Nowicki G. (red.). Ratownictwo medyczne - teraźniejszość i przyszłość. Lublin: Perfecta; 2012: 147-165.

2. Rębak D. Ratownik medyczny - kontrowersje na temat przygotowania zawodowego. Studia Med. 2011; 21: 79-83.

3. Kodeks etyki zawodowej ratownika medycznego. Kraków 2013.

4. Goniewicz M. Kształcenie ratowników medycznych w Akademii Medycznej im. prof. Feliksa Skubiszewskiego w Lublinie. W: Konieczny J. (red.). Ratownik medyczny problemy edukacyjne i organizacyjno-prawne. Poznań: Garmond Oficyna Wydawnicza; 2006: 31-39.

5. Cipora E, Bierawska J, Smoleń E. Zadowolenie z wykonywania zawodu ratownika medycznego - doniesienie wstępne. W: Cipora E. (red.). Ratownictwo w systemie bezpieczeństwa państwa. Sanok: PWSZ im. J. Grodka w Sanoku; 2014: 9-18.

6. Fedorczuk W, Pawlas K. Ryzyko zawodowe w pracy ratownika medycznego. Hygeia Public Health. 2011; 46 (4): 437-441.

7. Czarnecki KM, Czygier S. Zawód i praca człowieka. W: Czarnecki KM. (red.). Podstawowe pojęcia zawodoznawstwa. Sosnowiec: Oficyna Wydawnicza Humanitas; 2008: 75-124.

8. Borkowska S. System motywacyjny w przedsiębiorstwie. Warszawa: Wyd. PWN; 1985.

9. Ryan MN, Deci EJ. Self-determination theory and the facilitation of intrinsic motivation, social development and well-being. American Psychologist. 2000; 55: 68-78.

10. Kozłowski W. Zarządzanie motywacją pracowników. Warszawa: Wydawnictwo CeDeWu. 2009.

11. Elsbach KD, Hargadon AB. Enhancing creativity through „mindless” work: A Framework of Workday Design. Organization Science, 2006; 17(4): 470-483.

12. Jarecki W. Motywy wyboru studiów i kierunku studiów wyższych. Studia i prace wydziału Nauk Ekonomicznych i Zrządzania. Szczecin: Wydawnictwo Naukowe Uniwersytetu Szczecińskiego; 2008: 143-153.

13. Biuro Oceny Jakości Kształcenia. Badanie opinii absolwentów Uniwersytetu Medycznego w Lublinie rok 2012/2013. Lublin 2014.

14. Kapler M. Zawód: ratownik medyczny. Na Ratunek. Magazyn dla służb ratujących życie. 2012; 4: 43-46.

15. Rębak D. Przygotowanie ratowników medycznych do pełnienia funkcji zawodowych w świetle dwoistego systemu kształcenia. Studia Med. 2012; 25: 43-50.

16. Szczepańska B, Szady-Grad M, Klawe J, Kołodziejska K, Złotowska A. Plany zawodowe studentów fizjoterapii i ratownictwa medycznego Collegium Medicum w Bydgoszczy. Probl Hig Epidemiol. 2010; 91(4): 704-707.

17. Kropiwnicka E, Orzechowska A, Cholewska M, Krajewska-Kułak E. Determinanty wyboru zawodu, poziom aspiracji oraz plany na przyszłość studentów kierunku lekarskiego i pielęgniarstwa Uniwersytetu 
Medycznego w Białymstoku. Problemy Pielęgniarstwa. 2011; 19(1): $70-80$.

18. Fraś M, Turbiarz A, Kolonko J, Kadłubowska M, Kudłacik B. Pielęgniarskie studia licencjackie - wyobrażenia i rzeczywistość. Pielęgniarstwo XXI wieku. 2012; 4(41): 1-15.

19. Binkowska-Bury M, Marć M, Sobolewski M. Orientacja życiowa a czynniki motywujące młodzież do podejmowania kształcenia w zawodzie pielęgniarki w oparciu o badania studentów kierunku pielęgniarstwa
Uniwersytetu Rzeszowskiego. Przegląd Medyczny Uniwersytetu Rzeszowskiego. 2005; 2: 149-155.

20. Ustawa o Państwowym Ratownictwie Medycznym z dnia 1 lipca 2013 roku, poz. 757.

21. Rębak D, Głuszek S, Nowak-Starz G, Markowska M. Potrzeba ustawicznego kształcenia ratowników medycznych na tle innych zawodów regulowanych. Problemy pielęgniarstwa. 2012; 20(3): 327-337.

\title{
Effect of selected factors on the choice of study specialty and occupational plans among students of emergency medicine
}

\begin{abstract}
I Abstract
Introduction. Among the factors deciding about the choice of study specialty by young people are: interests, personal predispositions, and possibilities. The impact of the closest friends/family, mass media and prospects for finding employment with professional prospects are also of great importance.

Objective. The objective of the study was determination of factors affecting the choice of study specialty, and recognition of professional plans among students of emergency medicine.

Material and methods. The study was conducted in 2013 by the method of a diagnostic survey. In order to collect the empirical material, a questionnaire was used designed by the author. The study group were 133 students of the specialty of emergency medicine at the J. Grodek State Higher Vocational School in Sanok.

Results. In the majority of students in the study, being convinced by others was the factor deciding about the choice of emergency medicine as a profession, mainly among part-time students. A coincidence most frequently decided about the choice of the specialty of emergency medicine by urban inhabitants and female students. Females evaluated the possibilities of their employment in this profession in less optimistic terms than males. Males and persons aged 31-35, as well as urban inhabitants, after studies, planned to undertake work with the ambulance services, whereas females and part-time students - in a hospital emergency department. Full-time students and rural inhabitants intended to undertake employment with the State Fire Brigade. More than a half of respondents evaluated their opportunities for employment in accordance with the learned profession in high terms. In the respondents' opinions, studies, including practical and theoretical education, prepare the graduates for practicing their occupation. The students indicated that having a vocation is very important in the profession of a paramedic.

Conclusions. In the examined group, the variables correlating with the choice of study specialty were: gender, place of residence, students' age, and mode of studies.
\end{abstract}

\section{Key words}

students, profession, emergency medicine 